\title{
Nine weeks of supplementation with a multi- nutrient product augments changes in body composition, strength, and muscular performance in resistance trained men
}

\author{
JE Hofheins", R Lemieux, S Schmitz \\ From International Society of Sports Nutrition; 7th Annual ISSN Conference and Expo \\ Clearwater Beach, FL, USA. 24-26 June 2010
}

\section{Background}

The purpose of this study was to compare the effects of supplementation with SizeOn Maximum Performance ${ }^{\mathrm{Tm}}$ (SOmaxP) versus a comparator product $(\mathrm{CP})$ containing an equal amount of creatine $(4 \mathrm{~g})$ carbohydrate $(39 \mathrm{~g}$ maltodextrin) and protein ( $7 \mathrm{~g}$ whey protein hydrolysate) on muscular strength, muscular endurance, and body composition during nine weeks of intense resistance training.

\section{Methods}

Using a prospective, randomized, double-blind design, 20 healthy men (mean \pm SD age, height, weight, \% body fat: $22.9 \pm 2.6 \mathrm{y}, 178.4 \pm 5.7 \mathrm{~cm}, 80.5 \pm 6.6 \mathrm{~kg}, 16.6 \pm$ $4.0 \%)$ were matched for age, body weight, resistance training history, bench press strength, bench press endurance, and percent body fat and then randomly assigned via the ABBA procedure to ingest $1 / 2$ scoop (dissolved in $15 \mathrm{oz}$ water) of SOmaxP or CP prior to, and another $1 / 2$ scoop (dissolved in 15 oz water) during resistance exercise. Body composition (DEXA), muscular performance (1-RM bench press and repetitions to failure [RTF: 3 sets $x$ baseline body weight, 60 -sec rest between sets]), and clinical blood chemistries were measured at baseline and after nine weeks of supplementation and training. Subjects were required to maintain their normal dietary habits and follow a specific, progressive overload resistance training program (4-d/wk, upper body/lower body split) during the study. An intent-to-treat approach was used and data were

The Center for Applied Health Sciences, Division of Sports Nutrition and Exercise Science, Fairlawn, $\mathrm{OH}$ 44333, USA analyzed via ANCOVA using baseline values as the covariate. Statistical significance was set $a$ priori at $\mathrm{p} \leq 0.05$.

\section{Results}

When adjusted for initial differences, significant between group post-test means were noted in: 1-RM bench press (SOmaxP: $133.3 \pm 1.3 \mathrm{~kg}$ [19.8\% increase] vs. CP: 128.5 $\pm 1.3 \mathrm{~kg}$ [15.3\% increase]; $\mathrm{p}<0.019$ ); lean mass (SOmaxP: $64.1 \pm 0.4 \mathrm{~kg}$ [2.4\% increase] vs. $6 \overline{2.8 \pm 0.4} \mathrm{~kg}[0.27 \%$ increase], $\mathrm{p}<0.049$ ); $\mathrm{RTF}$ (SOmaxP: $33.3 \pm 1.1$ reps [44.8\% increase] vs. $27.8 \pm 1.1$ reps [ $20.9 \%$ increase], $\mathrm{p}<0.004$ ); and fat mass (SOmaxP: $12.06 \pm 0.53 \mathrm{~kg}[9.8 \%$ decrease] vs. $13.90 \pm 0.53 \mathrm{~kg}$ [4.1\% increase], $\mathrm{p}<0.024)$. No statistically significant differences in systemic hemodynamics (heart rate, systolic and diastolic blood pressures) or clinical blood chemistries (glucose, BUN-to-creatinine ratio, sodium, potassium, serum protein, albumin-to-globulin ratio, bilirubin, alkaline phosphatase, alanine aminotransferase, aspartate aminotransferase, total cholesterol, HDL-cholesterol, triacylglycerol, LDL-cholesterol, $\mathrm{CBC}$ ) were noted.

\section{Conclusions}

These preliminary data indicate that compared to $\mathrm{CP}$, SOmaxP administration augments gains in lean mass, bench press strength, and muscular performance during nine weeks of intense resistance training. Ongoing studies are attempting to confirm these results and clarify the molecular mechanisms by which SOmaxP exerts the observed salutary effects. 


\section{Acknowledgement}

Supported in part by a research grant from Gaspari Nutrition (Neptune, NJ).

Aside from S. Schmitz who is a Medical Consultant to Gaspari Nutrition,

none of the authors have any conflict of interest.

Published: 15 September 2010

doi:10.1186/1550-2783-7-S1-P14

Cite this article as: Hofheins et al:: Nine weeks of supplementation with a multi-nutrient product augments changes in body composition,

strength, and muscular performance in resistance trained men. Journal

of the International Society of Sports Nutrition 2010 7(Suppl 1):P14.

Submit your next manuscript to BioMed Central and take full advantage of:

- Convenient online submission

- Thorough peer review

- No space constraints or color figure charges

- Immediate publication on acceptance

- Inclusion in PubMed, CAS, Scopus and Google Scholar

- Research which is freely available for redistribution

Submit your manuscript at www.biomedcentral.com/submit
C Biomed Central 